\title{
Vitamin D as an accelerator of atherosclerotic calcification: a D-tail that may be a Trojan horse
}

\author{
M. E. Hellemons • S. J. L. Bakker
}

Received: 5 August 2010 /Accepted: 23 August 2010/Published online: 3 October 2010

(C) The Author(s) 2010. This article is published with open access at Springerlink.com

Keywords Adverse effects · Diabetes · Supplementation · Vascular calcification · Vitamin D

To the Editor: We read with great interest the article by Mathieu [1], which discusses whether vitamin D is important in diabetes. The author comes to several conclusions. The first is that severe vitamin D deficiency should be avoided in diabetes. We agree that the evidence is compelling. On the role for vitamin D supplementation above the threshold of vitamin D deficiency, it is concluded that high doses of 1,25-dihydroxyvitamin $\mathrm{D}$ reduce the incidence of diabetes in primary prevention studies in animal models. From this the author goes on to argue that carefully designed prospective placebo-controlled and randomised trials are required to provide definite answers as to the sense and non-sense of vitamin $\mathrm{D}$ supplementation in individuals affected by or at risk of type 1 and type 2 diabetes.

We completely agree: such trials are urgently needed, not only because science has already posed the question, but also because more and more people are actually supplementing themselves and their children on the basis of currently unjustified messages in the lay press.

The author mentions hypercalcaemia, hypercalciuria and kidney stones as potential adverse consequences of injudicious vitamin D supplementation. At this point we would like to add one other potentially even more important concern regarding the injudicious use of vitamin D

M. E. Hellemons · S. J. L. Bakker $(\bowtie)$

Department of Internal Medicine,

University Medical Center Groningen,

P.O. Box 30001, 9700 RB Groningen, the Netherlands

e-mail: s.j.1.bakker@int.umcg.nl

\section{E. Hellemons}

Department of Clinical Pharmacology,

University Medical Center Groningen,

Groningen, the Netherlands supplementation. It is well known that even mild prolonged increases in plasma calcium and plasma phosphate concentrations adversely affect the process of atherosclerotic calcification to an appreciable extent [2, 3]. Such changes could easily occur in response to vitamin D supplementation, increasing the already greater known risk of atherosclerotic vascular events in patients with diabetes and in persons at increased risk of developing diabetes $[4,5]$. It would therefore be highly relevant if future clinical trials on vitamin D supplementation were to include assessment of surrogate markers of atherosclerosis, measures of arterial calcification and assessment of cardiovascular events.

Acknowledgements Funding was provided by the EU Systems Biology towards Novel Chronic Kidney Disease Diagnosis and Treatment Project consortium (SysKid, EU FP7 project number 241544)

Duality of interest The authors declare that there is no duality of interest associated with this manuscript.

Open Access This article is distributed under the terms of the Creative Commons Attribution Noncommercial License which permits any noncommercial use, distribution, and reproduction in any medium, provided the original author(s) and source are credited.

\section{References}

1. Mathieu C (2010) Vitamin D and diabetes: the devil is in the D-tails. Diabetologia 53:1545-1548

2. Jono S, McKee MD, Murry CE et al (2000) Phosphate regulation of vascular smooth muscle cell calcification. Circ Res 87:E10-E17

3. Block GA, Hulbert-Shearon TE, Levin NW, Port FK (1998) Association of serum phosphorus and calcium x phosphate product with mortality risk in chronic hemodialysis patients: a national study. Am J Kidney Dis 31:607-617

4. Kannel WB, McGee DL (1979) Diabetes and glucose tolerance as risk factors for cardiovascular disease: the Framingham Study. Diabetes Care 2:120-126

5. Fox CS, Coady S, Sorlie PD et al (2004) Trends in cardiovascular complications of diabetes. JAMA 292:2495-2499 